\title{
Determining Teaching Competencies of Agricultural Education Programme Graduates of FCE (T) Gombe
}

\author{
Oguntunde, Gabriel Ayodele (Ph D) Harrison, Gideon Maghra \\ Department of Vocational and Technical Education, Adamawa State University, Mubi, Nigeria
}

\begin{abstract}
The purpose of this follow-up study was to evaluate the performance of Agricultural Education Graduates (AEGs) of the Federal College of Education (Technical) Gombe, from 1996 to 2003 who are teaching Agricultural Science in secondary schools in Gombe State; with the view to determine how effective they demonstrate the knowledge of vocational agriculture, the knowledge of pedagogy and the usefulness of the knowledge of general studies on their professional career. Data were collected using a researcher-developed questionnaire. The data collected were analyzed using weighed mean to answer 45 questions posed. Findings of the studies revealed that; AEGs are effective in eight out of ten vocational agriculture competency statements and that the knowledge of general studies is effective useful to AEGs' professional competency needs. It was recommended that equal and adequate attention be given to all aspect of the curriculum of agriculture by agriculture teacher trainers. Teaching and learning environment in secondary schools should be motivating and conducive for the students to develop interest in agriculture.
\end{abstract}

Keywords: Teaching competencies, Agricultural education graduates, Vocational agriculture

DOI: $10.7176 / \mathrm{JEP} / 11-19-08$

Publication date:July $31^{\text {st }} 2020$

\section{INTRODUCTION}

Vocational Agriculture was introduced in Nigeria's formal education system over two decades ago consequent upon the National Policy on Education document first published in 1977 revised in 1981, 1998 and 2004. As an innovation in the agricultural education programme, Nigeria agricultural educators fashioned out vocational agriculture at the secondary school level to suit the need of the nation. In its broad content, vocational agriculture in secondary school is concerned with the development of skills, knowledge and attitude in the field of agriculture to enable the students to take up career in it (Ezeagu \& Ezema, 2004). Makusidi (2016), opined that vocational agricultural education leads individual directly to a particular function in society which is to be employed in job trade or private occupation. Unlike vocational agriculture, the form of agricultural science that was offered in schools prior to the introduction of the 6:3:3:4 system of education focused on the discipline and sub discipline approach to learning. Under the discipline approach to learning, learners were exposed to scientific methods and techniques in agriculture without relating them to the world of work, leading to the production of a crop of theories who were capable of theorizing concepts, methods and techniques for improving farming but lack psychoproductive skills required on actual jobs. This obviously resulted in a conflict between what was operating and what was required. The apparent failure of the agricultural training to meet the yearnings and aspirations of the Nigerian people led to the call by some Nationalist for a total review of the curriculum of education, which invariably effected agricultural education (Fafunwa, 1974).

Ishyaku (2002;a) reported that it was the Ashby commission of 1960, Adam Skapski's report of 1966 and the curriculum conference of 1969 , which provided the impetus that eventually brought vocational education (including agricultural education) to the limelight. At the secondary school level, the content of agriculture is organized into pre-vocational and vocational agriculture for the junior and secondary school levels respectively. At the Junior Secondary School (JSS), which is currently referred to as Senior Basic level, vocational agriculture is offered as a pre-vocational subject. The content of the curriculum for JSS provides that vocational agriculture should among other thing stimulate student's interest in agriculture, enable students acquire basic knowledge in agriculture, prepare students for occupation in agriculture and prepare students for further studies in agriculture (FRN, in Abelega, 1996:81). Therefore, based on the structure, objectives and content of vocational agriculture in the National Policy on the inadequacies that were hitherto associated with the form of agricultural science that was offered in secondary schools. The innovations introduced to Agricultural Education was however, faced with the problem of shortage of teachers, who will implement the new policy at the secondary school level. Apagu (2001) argued that teachers who are occupationally qualified and competent in the subject-matter area contribute immensely to the success of any educational programme. This is also true for vocational agriculture teachers. Competent teachers are required in adequate quantity to guide and direct learning.

In the view of Ndubisi and Ali, (1986) the Universal Primary Education (UPE) scheme launched by the Federal Government of Nigeria in 1976, led to enrolment explosion in primary and secondary schools. In addition, qualified and experienced teachers were in very short supply, especially at the JSS level. Agricultural education, being a component part of secondary education, will invariably be affected by shortage of manpower which led to 
government established of the second National Technical Teachers' College (NTTC), in Gombe in 1977, now called Federal College of Education Technical, to complement the one at Yaba to train technical teachers specifically for the JSS level.

The programme leads to the award of the Nigerian Certificates in Education (NCE) Technical. FCE (T), Gombe was however affiliated to the Institute of Education Ahmadu Bello University Zaria, from its establishment in 1977 until 1992 when autonomy was granted to colleges of Education, under the supervision of the National Commission for Colleges of Education (NCCE). The NCCE, according to Ibitoye and Daluba (2000:176) "is charged with the responsibility of preparing minimum standards for the programme of Colleges of Education and also set out guidelines and criteria for their accreditation in accordance with the National Policy on Education." The College started training in Agricultural Education in 1987 with the first set of student teachers graduating in 1990. The objectives of NCE Agricultural Education include, producing competent teachers with the knowledge of vocational agriculture, pedagogical skills and general studies, (NCCE, 1996:1). A competent agriculture teacher according to Dormody and Torres (2002) should possess subject-matter competence, pedagogical competence, skills processes and disposition necessary to help all students learn. Agriculture teacher education programme is categorized into; General education components, technical and professional agricultural components, general studies, teaching practice and student' competency needs. Isyaku (2002:b) stressed that a viable teacher education programme should ensure that its products, apart from being masters of their subjects and of the techniques and the skills of teaching - in the case of this study, vocational agriculture - must be exposed to the beneficial influences of the humanistic studies which features in the foundations of education. It is therefore important for the agriculture teacher educators to guarantee the production of well-nurtured individual who has a thorough knowledge of the psychological basis and techniques for identifying, integrating and using appropriate skills for communicating content to the student.

Based on the conceptualization by Finch and Crunkilton (1984) that teaching and learning are partnerprocesses, the programme for producing such competency-based and performance oriented agriculture teachers must not compromise quality. Inadequacies and deficiencies, should not be allowed to exist in any curriculum components, or else the objectives of the programme become defeated, leading to a state of wastage in terms human and material resources. Frequent evaluation is therefore required in order to avoid failure and ensure programme effectiveness.

Programme evaluation according to Okoro (2000) involves the collection of data and the use of such data to assess the effectiveness or quality of programme. It is the process of comparing programme performance against the desired programme standards to determine if there is any discrepancy between the two. The information obtained from the study can then be used to improve the programme. In addition to this general value of evaluation, an effective evaluation in vocational agriculture education programme is expected to serve as a pivot for producing competent, functional and production-oriented graduates who will work to achieve the objectives of the agricultural education programme they passed through. One major technique in programme evaluation is the follow-up study. A follow-up study involves contacting individuals after they have passed through a training programmme in order to ascertain from them what they think of the programme they passed through (Okoro,2000). Employer survey, according to Okoro (2000) can also form a part of a follow-up study.

Finch and McGough (1982) argue that when effort to carry out programme evaluation is being formalized, it is sometimes best to build it upon a conceptual framework. Finch and McGough view evaluation of vocational education curricula, programmes and services as being related to initiation, structuring and operation of the school system. Evaluation of a school programmes are then modeled into four stages: Context Evaluation; Input Evaluation; Process Evaluation and Product Evaluation. Context, Input, Process and Product (CIPP) evaluation are the most useful elements of a comprehensive evaluation framework. Context and input evaluation are most appropriate when initiation and structuring activities are to be conducted, while the process and product evaluation relate most closely to operation activities. Context and input evaluation help in making decision as to whether or not to establish a curriculum or what content should be included in a programme. Process or product evaluation, on the other hand, relate to whether or not students have leraned certain content and the effects such content has on students, such as their ability to secure employment and how well they are performing on the job. (Finch and McGough, 1982; Okoro,1999; Okoro, 2000 and Ajala, 2002). It was therefore the crux of this study to carryout process and product analysis of the graduates of NCE agriculture programme.

F.C.E (T) Gombe was established in 1977 and has been graduating NCE agriculture teachers since 1991; most of whom reside and teach in secondary schools in the state; and since the NCE agriculture programme was well conceived and currently being executed based on outstanding process of admission, curriculum implementation and evaluation, it is hoped to be yielding expected results. The level of professional competencies of these graduates has however not been determined before now. Considering also that we are living in a dynamic society that is constantly being influenced by innovations in teacher education, which requires that adequate attention be given to the process of producing such teachers. The extent to which the NCE agriculture programme of F.C.E (T) Gombe has prepared its graduates in subject matter and pedagogical competences and knowledge of 
general studies, so as to effectively teach agriculture in secondary schools was therefore the concern of this study.

\subsection{Purposes and Objectives}

The main purpose of this study was to evaluate the performance of Agricultural Education Graduates (AEGs) of FCE (T) Gombe currently teaching in secondary schools in Gombe State. Specifically, the objectives of the study were: -

i. To determine how effective the AEGs of FCE (T) Gombe demonstrate the knowledge of vocational agriculture during their day-to-day teaching activities.

ii. To determine how effective the AEGs of FCE (T) Gombe demonstrate the skills of teaching agriculture.

iii. To evaluate the usefulness of the knowledge of general studies to the professional needs of AEGs.

\subsection{Research Questions}

The following research questions were answered in this study:

i. How effective do AEGs demonstrate the knowledge of vocational agriculture during their day-to-day teaching activities?

ii. How effective do AEGs demonstrate the skills of teaching agriculture?

iii. How useful is the knowledge of general studies to AEGs professional needs?

\section{Methods and Procedures}

A survey design was adopted for the study. The design was considered suitable and appropriate for this study because it involves collection of data through questionnaire from a representative sample of the population. The population for this study consisted of 486 AEGs of FCE (T) Gombe that graduated between 1996 and 2003 who are residents in Gombe State. Agricultural Education Graduates' supervisors that made up the second population of the study were the 150 principals and 150 Heads of Department of agriculture found in the 150 secondary schools in Gombe State (Gombe State Ministry of Education, 2004). The Taro Yamane formular for a finite population was used to determine the sample size. A sample of 219 AEGs, representing $45 \%$ of the population was considered for the study. The sampling technique adopted in the study was Simple Random Sampling. The instrument used for data collection was a questionnaire titled Agricultural Education Graduates Follow-up Questionnaire I and II (AEGFUQ). AEGFUQ I was designed for AEGs, while AEGFUQ II was for Principal and HODs. However, they both contain the same questionnaire items except for differences in general information and mode of questioning. The AEGFUQ consisted of 45 questionnaire items in three sections A, B and C. The questionnaire began with a preliminary section titled; General Information, which was designed to collect information about the respondents' year of graduation and current place of work. Section A of the instrument contained 10 questionnaire items subject-matter knowledge of AEGs. Section B contained 20 questionnaire items on pedagogic knowledge of AEGs. While section $\mathrm{C}$ had 15 questionnaire items on general knowledge acquired by AEGs during training. All the questionnaire items were structured into five-response category. Experts validated the instruments, while reliability test yielded Cronbach alpha 0.81 . Data collected in the study were analyzed using Minitab version 10 to determine the Mean (X). Grand Mean (X) was used to analyze the mean responses of the three groups of respondents in respect of each item on the questionnaire.

\section{Results and Discussion}

Objective 1

Table 1 indicates that AEGs fairly effectively demonstrate the knowledge of vocational agriculture in eight (8) out of ten (10) competency items. They were rated ineffective in two, that is, items 3 and 4 . The highest grand mean of 3.31 is for demonstration of the knowledge to form youth clubs in school, while the lowest grand of 2.27 indicate AEGs' ineffectiveness in the knowledge of animal production and ability to maintain soil fertility in the school farm. 
Table I

AEGs Knowledge of Vocational Agriculture

\begin{tabular}{|l|l|l|l|l|l|l|}
\hline $\begin{array}{l}\text { ITEM } \\
\text { NO. }\end{array}$ & Vocational agriculture competencies & $\begin{array}{l}\text { AEG } \\
\mathrm{X}_{1} \\
\mathrm{~N}=200\end{array}$ & $\begin{array}{l}\text { PRIN } \\
\mathrm{X}_{2} \\
\mathrm{~N}=128\end{array}$ & $\begin{array}{l}\text { HOD } \\
\mathrm{X}_{3} \\
\mathrm{~N}=128\end{array}$ & $\begin{array}{l}\text { GRAND } \\
\text { MEAN }\end{array}$ & REMARKS \\
\hline 1. & Knowledge of basic sciences & 2.980 & 3.172 & 3.305 & 3.152 & Fairly Effective \\
\hline 2. & $\begin{array}{l}\text { Ability to conduct agriculture } \\
\text { practical }\end{array}$ & 2.435 & 3.484 & $3-086$ & 3.002 & Fairly Effective \\
\hline 3. & $\begin{array}{l}\text { Demonstration of knowledge of } \\
\text { animal product }\end{array}$ & 2.165 & 2.781 & 3.227 & 2.724 & Ineffective \\
\hline 4. & $\begin{array}{l}\text { Ability to maintain soil fertility in the } \\
\text { school }\end{array}$ & 3.040 & 2.539 & 3.414 & 2.998 & Ineffective \\
\hline 5. & $\begin{array}{l}\text { Ability to form youth clubs in the } \\
\text { school }\end{array}$ & 3.200 & 3.227 & 3.508 & 3.311 & Fairly Effective \\
\hline 6. & $\begin{array}{l}\text { Knowledge of agricultural marketing } \\
\text { Knowledge of crop husbandry }\end{array}$ & 3.540 & 3.250 & 3.023 & 3.271 & $\begin{array}{l}\text { Fairly } \\
\text { Effective }\end{array}$ \\
\hline 7. & Knowledge of agricultural tools & 3.880 & 2.938 & 3.070 & 3.296 & Fairly Effective \\
\hline 8. & Implements knowledge agricultural & 4.050 & 2.906 & 2.773 & 3.243 & Effective \\
\hline 9. & Climatology & 3.650 & 2.594 & 2.773 & 3.006 & $\begin{array}{l}\text { Fairly } \\
\text { Effectiveness }\end{array}$ \\
\hline 10. & & & & & & \\
\hline
\end{tabular}

Note: $X_{1}-$ Mean of AEGs; $X_{2}-$ Mean of Principals; $X_{3}-$ Mean of HODs

The implication of the findings in Table 1 is that there should be concerted effort to improve the strategies of teaching those aspects of the subject matter where AEGs' teachers were rated ineffective, because Abelega (1996) and Isyaku (2002), said to effectively teach all the subject areas of agriculture and other subject matter specializations the high competence level of AEGs recorded in the knowledge of vocational agriculture could attributed to a total of 72 credit units allotted to vocational agriculture out of 130 total credit units required for graduation in NCE agriculture.

Objective 2

Table 2 reveals that out of 20 questionnaire items AEGs are ineffective in the use of instructional materials. The mean response was however close to 3.00; that is 2.98 . The highest grand means obtained were $3.837,3,731$, and 3.731 respectively. These mean scores indicate effective demonstration of the skills of teaching agriculture, in the areas of rapport with students, demonstration of comportment during teaching and effective use of chalkboard.

Table 2

AEGs Demonstration of Teaching Skills

\begin{tabular}{|c|c|c|c|c|c|c|}
\hline $\begin{array}{l}\text { ITEMS } \\
\text { NO. }\end{array}$ & Pedagogic Competencies & $\begin{array}{l}\text { AEG } X_{1} \\
\mathbf{N}=\mathbf{2 0 0}\end{array}$ & $\begin{array}{l}\text { PRIN X2 } \\
N=128\end{array}$ & $\begin{array}{l}\text { HOD } X_{3} \\
N=128\end{array}$ & $\begin{array}{l}\text { GRAND } \\
\text { MEAN }\end{array}$ & REMARKS \\
\hline 1. & $\begin{array}{l}\text { Knowledge of lesson plan } \\
\text { organization }\end{array}$ & 4.090 & 3.273 & 3.469 & 3.611 & Effective \\
\hline 2. & $\begin{array}{l}\text { Ability to introduce lesson in } \\
\text { a variety of ways }\end{array}$ & 4.020 & 2.992 & 2.797 & 3.270 & $\begin{array}{l}\text { Fairly } \\
\text { Effective }\end{array}$ \\
\hline 3. & $\begin{array}{l}\text { Use of appropriate teaching } \\
\text { methods }\end{array}$ & 4.030 & 2.359 & 3.391 & 3.260 & $\begin{array}{l}\text { Fairly } \\
\text { Effective }\end{array}$ \\
\hline 4. & $\begin{array}{l}\text { Ability to work with diverse } \\
\text { student. }\end{array}$ & 3.645 & 2.820 & 3.508 & 3.324 & $\begin{array}{l}\text { Fairly } \\
\text { Effective }\end{array}$ \\
\hline 5. & Population & 4.115 & 3.195 & 3.883 & 3.726 & $\begin{array}{l}\text { Fairly } \\
\text { Effective }\end{array}$ \\
\hline 6. & Use of chalkboard & 3.905 & 3.445 & 3.828 & 3.726 & Effective \\
\hline 7. & Time management ability & 3.675 & 2.281 & 2.984 & 2.980 & Effective \\
\hline 8. & $\begin{array}{l}\text { Use of instructional } \\
\text { materials. }\end{array}$ & 3.475 & 2.633 & 3.133 & 3.080 & Ineffective \\
\hline 9. & $\begin{array}{l}\text { Identify individual } \\
\text { differences in students and } \\
\text { reflect it in planning. }\end{array}$ & 3.730 & 3.344 & 3.281 & 3.452 & $\begin{array}{l}\text { Fairly } \\
\text { Effective }\end{array}$ \\
\hline 10. & $\begin{array}{l}\text { Achievement of lesson } \\
\text { objectives. }\end{array}$ & 4.475 & 3.508 & 3.289 & 3.757 & \\
\hline 11. & $\begin{array}{l}\text { Demonstrate an in charge- } \\
\text { image (comportment). }\end{array}$ & 4.330 & 3.008 & 3.664 & 3.667 & $\begin{array}{l}\text { Fairly } \\
\text { Effective }\end{array}$ \\
\hline
\end{tabular}




\begin{tabular}{|c|c|c|c|c|c|c|}
\hline $\begin{array}{l}\text { ITEMS } \\
\text { NO. }\end{array}$ & Pedagogic Competencies & $\begin{array}{l}\text { AEG } X_{1} \\
\mathbf{N}=\mathbf{2 0 0}\end{array}$ & $\begin{array}{l}\text { PRIN } X_{2} \\
N=128\end{array}$ & $\begin{array}{l}\text { HOD X }_{3} \\
N=128\end{array}$ & $\begin{array}{l}\text { GRAND } \\
\text { MEAN }\end{array}$ & REMARKS \\
\hline 12. & $\begin{array}{l}\text { Ability to keep students on } \\
\text { task. }\end{array}$ & 4.390 & 2.945 & 3.563 & 3.633 & Effective \\
\hline 13. & $\begin{array}{l}\text { Apply appropriate classroom } \\
\text { management skills. }\end{array}$ & 3.675 & 2.719 & 2.867 & 3.087 & Effective \\
\hline 14. & $\begin{array}{l}\text { Knowledge of improvisation } \\
\text { of simple instructional } \\
\text { materials. }\end{array}$ & 3.460 & 3.203 & 3.156 & 3.273 & Effective \\
\hline 15. & $\begin{array}{l}\text { Ability to provide career } \\
\text { information to students. }\end{array}$ & 3.725 & 2.570 & 2.758 & 3.018 & $\begin{array}{l}\text { Fairly } \\
\text { Effective }\end{array}$ \\
\hline 16. & Appropriate use of language. & 4.160 & 3.172 & 3.258 & 3.530 & $\begin{array}{l}\text { Fairly } \\
\text { Effective }\end{array}$ \\
\hline 17. & $\begin{array}{lll}\begin{array}{l}\text { Present } \\
\text { clearly. }\end{array} & \text { subject } & \text { matter } \\
\end{array}$ & 4.290 & 3.125 & 3.555 & 3.657 & Effective \\
\hline 18. & $\begin{array}{l}\text { Use appropriate strategies to } \\
\text { evaluate learning. }\end{array}$ & 4.225 & 2.172 & 3.031 & 3.143 & $\begin{array}{l}\text { Fairly } \\
\text { Effective }\end{array}$ \\
\hline 19. & Questioning technique. & 3.340 & 2.664 & 3.016 & 3.007 & Effective \\
\hline 20. & $\begin{array}{l}\text { Demonstrate knowledge of } \\
\text { teaching as a profession. }\end{array}$ & 4.480 & 3.641 & 3.391 & 3.837 & Effective \\
\hline
\end{tabular}

Note: X1 - Mean of AEGs; X2 - Mean of Principals; X3 - Mean of HODs

The second purpose of this study indicated that on a general note, AEGs effectively demonstrated pedagogical skills. Pedagogical knowledge is the professional education component of the agriculture teacher education programme. However, Table 2 shows that, of all the 20 questionnaire items only one aspect of the teaching skills was rated ineffective. That is, the use of instructional materials. This implies that AEGs do not effectively demonstrate the knowledge of the use instructional materials. This finding conforms with the discovery of Ogunrinde (2002), which revealed that agriculture teachers tend to concentrate on imparting cognitive knowledge to students at the detriment of the much-desired psycho-productive skills. The same result can be responsible for students declining interest in agriculture (Ogunrinde, 2002). This finding therefore will serve as, feedback to teacher educators because follow-up studies provide feedback to teachers concerning the effectiveness of their teaching methods, thereby increasing their understanding of the needs of their current students.

Objective 3

Table 3 shows that knowledge of general studies acquired by AEGs effectively contribute to their professional teaching activities in thirteen (13) out of fifteen (15) questionnaire items. The highest grand means being 3.737 and 3.735 that measured AEGs' interpersonal relationship with other staff and team spirit respectively. Areas of ineffectiveness include ability to communicate effectively in English and Knowledge of the use of library, which both have means of 2.999 and 2.370 respectively.

Table 3

Usefulness of the Knowledge of General Studies to AEGs

\begin{tabular}{|l|l|l|l|l|l|l|}
\hline $\begin{array}{l}\text { ITEM } \\
\text { NO. }\end{array}$ & $\begin{array}{l}\text { Usefulness of Knowledge } \\
\text { General }\end{array}$ & $\begin{array}{l}\text { AEG X } \\
\mathbf{N = 2 0 0}\end{array}$ & $\begin{array}{l}\text { PRIN X } \\
\mathbf{N = 1 2 8}\end{array}$ & $\begin{array}{l}\text { HOD X3 } \\
\mathbf{N = 1 2 8}\end{array}$ & $\begin{array}{l}\text { GRAND } \\
\text { MEAN }\end{array}$ & REMARKS \\
\hline 1. & $\begin{array}{l}\text { Ability to communicate } \\
\text { effectively in English } \\
\text { language }\end{array}$ & 3.560 & 2.828 & 2.609 & 2.999 & Ineffective \\
\hline 2. & $\begin{array}{l}\text { Participation in Unions and } \\
\text { Association }\end{array}$ & 3.645 & 3.242 & 3.266 & 3.384 & $\begin{array}{l}\text { Fairly } \\
\text { Effective }\end{array}$ \\
\hline 3. & $\begin{array}{l}\text { Interpersonal relationship } \\
\text { with students }\end{array}$ & 3.790 & 3.734 & 3.281 & 3.602 & Effective \\
\hline 4. & $\begin{array}{l}\text { Interpersonal relationship } \\
\text { with other staff. } 3.925\end{array}$ & 3.898 & 3.383 & 3.735 & Effective \\
\hline 5. & $\begin{array}{l}\text { Attitude to work. } \\
\text { Judgment ability to make } \\
\text { worthwhile decisions. }\end{array}$ & 4.210 & 3.492 & 3.703 & 3.737 & Effective \\
\hline 6. & $\begin{array}{l}\text { Initiative and innovation } \\
\text { Team Spirit }\end{array}$ & 4.210 & 3.375 & 3.453 & 3.714 & Effective \\
\hline 7. & Punctuality & 4.250 & 3.438 & 3.36 & 3.721 & Effective \\
\hline 8. & $\begin{array}{l}\text { Cooperation with school } \\
\text { administration. }\end{array}$ & 4.265 & 3.531 & 3.25 & 3.675 & Effective \\
\hline 9. & & & 3.414 & 3.438 & 3.710 & Effective \\
\hline 10.
\end{tabular}




\begin{tabular}{|c|c|c|c|c|c|c|}
\hline $\begin{array}{l}\text { ITEM } \\
\text { NO. }\end{array}$ & $\begin{array}{l}\text { Usefulness of Knowledge } \\
\text { General }\end{array}$ & $\begin{array}{l}\text { AEG X } \\
N=200\end{array}$ & $\begin{array}{l}\text { PRIN } X_{2} \\
N=128\end{array}$ & $\begin{array}{l}\text { HOD X } \\
N=128\end{array}$ & $\begin{array}{l}\text { GRAND } \\
\text { MEAN }\end{array}$ & REMARKS \\
\hline 11. & Knowledge of National Issues & 4.305 & 3.461 & 2.633 & 2.370 & Effective \\
\hline 12. & Writing skills & 4.130 & 3.469 & 3.031 & 3.228 & Effective \\
\hline 13. & $\begin{array}{l}\text { Knowledge of the use of } \\
\text { library. }\end{array}$ & 2.125 & 2.352 & & 3.547 & Ineffective \\
\hline 14. & $\begin{array}{l}\text { Community development } \\
\text { activities }\end{array}$ & 3.590 & 3.063 & 3.438 & & Effective \\
\hline 15. & $\begin{array}{l}\text { Recognition of rights, } \\
\text { privileges and responsibilities } \\
\text { as a citizen }\end{array}$ & 3.625 & 3.578 & & & Effective \\
\hline
\end{tabular}

Note: $\mathrm{X}_{1}$ - Mean of AEGs; $\mathrm{X}_{2}$ - Mean of Principals; $\mathrm{X}_{3}$ - Mean of HODs

Objective 3 diagnosed some personality traits possessed by AEGs since according to Ajala (2002) teachers need to be evaluated on several traits among which are intelligence, personality, punctuality and general relationship with both staff and students. Table 3 shows that AEGs are effective in the knowledge of general studies but their performances in the use of English language and library were rated ineffective. It therefore goes to say that the common notion by science and technology students that the knowledge of English Language is not important, is a global trend and teacher educators should make deliberate effort to improve strategies of teaching communication Skills in schools at all levels. Another area of AEGs ineffectiveness is in the use of library. This could also be attributed to poor library facilities in secondary schools, because adequate credits are allotted to study in the use of library in the NCCE Minimum Standards. Dormody and Torres (2002) in a study of graduates of Agricultural Education who have taught for an upward period of five years in secondary schools were found to have improved in teacher competency abilities due to experience acquired on the job. Therefore, if there were adequate library facilities in schools the knowledge of AEGs in the use of library would have improved over time.

\section{Conclusion}

Based on the results of this study, the following conclusions were drawn:

1. The performance level of AEGs in the knowledge and demonstration of vocational agriculture is generally effective except in the aspect of animal production and soil fertility improvement.

2. The Pedagogic skills demonstrated by AEGs are within acceptable limit but they need to improve in the use of instructional materials in teaching.

3. Knowledge of general studies contributes effectively to the satisfaction of AEGs' professional teacher requirements, but they need to improve in the use of library, communicational skills and computer.

\section{Recommendations}

The following recommendations were made based on the findings of this study.

1. Agriculture teacher trainers should make sure that all the aspects of agriculture are given adequate and equal attention in order to produce well balance and competent agriculture teachers for schools.

2. Agriculture teacher training should emphasize the use of instructional aids during training and also give adequate attention to skills of improvisation.

3. School should provide adequate instructional materials for agriculture teachers to use especially practical farms where most of the items needed for effective teaching of agriculture can be found.

4. During teacher training, more attention should be given to studies in the use of library especially by adopting teaching strategies that will make student teachers develop positive attitude to the use of library.

\section{References}

Abelega, M.A. (1996). Work-Oriented Education in Agriculture: Implications for Quality Agricultural Programmes in Nigerian Universities. The Nigerian Teacher Today. 7 (1), 179 - 189.

Ajala, J.A. (2002). Research and Evaluation Practice in Curriculum Development. In Ajala, J. (Ed), Designing Content of the Curriculum: A guide to practice (Pp. 239- 258). Ibadan: May Best.

Apagu, V.V. (2001). Qualities and Competencies for Effective Teaching of Vocational and Technical Courses. In Apagu, V.V and John, A.C (Eds). Technical Education Department, Federal University of Technology.

Dormody, T.J. \& Torres, R.M. (2002). A Follow-up Study of Agricultural Education Programme Graduates on Teaching Competencies. Journal of Agricultural Education, 43 (4), 33 - 45.

Ezeagu, S. E. \& Ezema, P. N. (2004). Introduction to Vocational Education. Enugu:OzyBel Publishers. Pp. 32.

Fafunwa, B.A. (1974). History of Education in Nigeria. London: George Allen and Unwin

Federal Government of Nigeria (2002). National Policy on Education. Abuja: Federal Ministry of Education.

Finch, C.R., \& Crunkilton, J.R. (1984). Curriculum Development in Vocational and Technical Education:

Planning content and implementation. Newton, M.A,: Allyn and Bacon, Inc. 
Finch, C.R., \& McGough, R. (1982). Administering and Supervising Occupational Education. Englewood Cliffs, N.J.: Prentice - Hall, Inc.

Gombe State Ministry of Education (2004). Secondary schools in Gombe State. Annual Report. Gombe: Ministry of Education.

Ibitoye, S. \& Daluba, N.E. (2000). An Appraisal of the Agriculture Education Curriculum in the NCCE Minimum Standards for NCE Teachers. The Nigeria Teacher Today. 8 (1 \& 2), 176 - 183.

Isyaku, K. (2002:a). Teacher Education for Modern Nigeria. In Anikweze, C.M., Ojo, M.O \& Maiyanga, A.A. (Eds) Teacher Education in Nigeria: Reflection of Dr. Kabiru Isyaku. Abuja: NCCE.

Isyaku, K. (2002:b). The Imperative of Curriculum Review: The NCCE example. In Anikweze, C.M., Ojo, M.O. \& Maiyanga, A.A. (Eds) Teacher Education in Nigeria: Reflections of Dr. Kabiru Isyaku. Abuja NCCE.

Makusidi, H. M. (2016). The Role of Vocational Agricultural Education in National Development. Capital Journal of Education Studies; Vol. 4 (1).

National Commission for Colleges of Education (1996). Minimum standards for NCE Teachers (2 ${ }^{\text {nd }}$ ed). Kaduna: NCCE.

National Commission for Colleges of Education (1999)., Statistical digest on College of Education in Nigeria Kaduna: F. Abdulrahman Printers and Publishers.

Ndubisi. A and Ali. A. (1986). An Evaluation of In-service Sandwich Programme of the Institute of Education University of Nigeria, Nsukka.

Ogunride, S. I. (2000). Competency-based Education: A base line for vocational technical agriculture in Nigeria. An invited paper presented at Annual Conference of the National Council for Colleges of Education (NCCE). Held at NCCE-Kaduna, $21^{\text {st }} \quad 23^{\text {rd }}$ August,2002.

Okoro, O.M. (2000). Programme Evaluation in Education Oruwulu-Obisi: Pacific Publishers. 